\title{
Psalm 32: A social-scientific investigation
}

Phil J. Botha (University of Pretoria)

\begin{abstract}
The article identifies the root metaphors used in Ps 32 and uses these to identify the purpose and strategy of the psalm as a means of communication between its author and its original audience. It argues that the psalm should not be read as a psalm of thanksgiving with wisdom elements, but a wisdom-teaching psalm which replicates a psalm of thanksgiving. The author and/or editors used the composition, which is ascribed to King David, as a means of exhorting members of the in-group in a post-exilic setting in Judah to trust in YHWH and to stay faithful to him. The implied author's experience of suffering because of pent-up guilt, as well as an authoritative first-person address by $\mathrm{YHWH}$, was used in conjunction with a range of wisdom features by the author to communicate this message to its original audience.
\end{abstract}

KEYWORDS: Psalm 32; strategy; wisdom; trust; sin; guilt; suffering.

\section{A INTRODUCTION}

This article offers a social-scientific analysis of Ps 32, aimed at determining what the author of the psalm and/or the editors of the Psalter wanted to communicate with it. As such it is an attempt to correlate the literary, poetic, cultural, anthropological, theological and social dimensions of the psalm. ${ }^{1}$ The incentive for the investigation is the fact that the exegesis of Ps 32 is usually still undertaken from the premise that it, or a kernel composition recognisable as its basis, was intended to constitute thanksgiving in a liturgical context. It was namely described by Gunkel ${ }^{2}$ as a psalm of thanksgiving of an individual into

* Submitted: 27/09/2018; peer-reviewed: 31/10/2018; accepted:19/02/2019. Phil J. Botha, "Psalm 32: A social-scientific investigation," Old Testament Essays 32 no. 1 (2019): 12-31. DOI: https://doi.org/10.17159/23123621/2019/v32n1a3.

1 Cf. the definition of "social-scientific criticism" by John H. Elliott, What is socialscientific criticism? (GBS; Minneapolis: Fortress, 1993), 7. I have added "anthropological" to this definition. Cf. also John H. Elliott, "Social-scientific criticism. Perspective, process and payoff: Evil eye accusation at Galatia as illustration of the method," HTS Teologiese Studies/Theological Studies 67, 1-10, 1-2 on socialscientific criticism as an investigation of biblical texts "as meaningful configurations of language intended to communicate between composers and audiences."

2 Herman Gunkel, Die Psalmen, übersetzt und erklärt (6. Auflage; Göttingen: Vandenhoeck \& Ruprecht, 1986), 135. 
which wisdom motifs were integrated. This classification is so deeply embedded ${ }^{3}$ that thanksgiving in a temple milieu still serves as its hermeneutic horizon although wisdom characteristics overshadow the motifs of a psalm of thanksgiving. ${ }^{4}$ Interpreting the psalm against the setting of thanksgiving has unfortunately led to wrong assessments of its quality. ${ }^{5}$ It should not be read as a

3 Hans-Joachim Kraus, Psalmen, 1. Teilband (BKAT 15/1, 5. Auflage; NeukirchenVluyn: Neukirchener, [1961] 1978), 401 says it wants to be understood as a "Toda," a song of thanksgiving of an individual. The typical characteristics of such a psalm which, in his view, are found here, are a description of distress, a call to God, an experience of help, and thanksgiving or call to praise. Kraus also says, however, that the influence of wisdom teaching is undeniable. Artur Weiser, Die Psalmen, Erster Teil: Psalm 1-60 (ATD, 4. Auflage; Göttingen: Vandenhoeck \& Ruprecht, 1955), 189 also describes it as a psalm of thanksgiving which looks back at penitence and forgiveness and draws teaching from the personal experience of the psalmist for every pious person. FrankLothar Hossfeld and Erich Zenger, Die Psalmen I: Psalm 1-50 (NEB; Würzburg: Echter Verlag, 1993), 201 describe Ps 32 as a wisdom-coined psalm of thanksgiving of an individual, based on a foundational composition whose remains are visible in verses $1-5,7-8$, and 11. According to them (p. 200), the "YHWH-oracle" in v. 8 attracted wisdom additions which they describe as being visible in wisdom speech forms. Samuel Terrien, The Psalms: Strophic structure and theological commentary (ECC; Grand Rapids: Eerdmans, 2002), 292 describe the psalm as "a penitential prayer of avowal and forgiveness."

4 Peter C. Craigie and Marvin E. Tate, Psalms 1-50: With 2004 supplement by Marvin E. Tate (WBC; Nashville: Thomas Nelson, 2004), 265 is one notable exception to the rule. He suggests that the psalm should be interpreted "as a literary composition, in which a basic thanksgiving psalm has been given literary adaptation according to the wisdom tradition." He also refers to Roland E. Murphy's classification of the psalm as a wisdom psalm: Roland E. Murphy, "A consideration of the classification 'Wisdom Psalms,"” pages 156-167 in Baumgartner, Walter (ed.), Congress volume. Congress of the International Organization for the Study of the Old Testament, Bonn 1962 (Supplements to Vetus Testamentum, 9; Leiden: Brill 1963), 161. The wisdom elements include, according to Hossfeld and Zenger, Die Psalmen I, 200 macarisms in vv. 1-2, admonishments in vv. 6 and 9 and a maxim in v. 10; wisdom vocabulary such as "instruct," "teach," and "counsel" in v. 8; a "road" metaphor in v. 8; animal comparisons in v. 9; and equation of the "righteous" with the "upright in heart" in v. 11. Further wisdom concepts that are used according to them include the contrast between "righteous" and "wicked" people in v. 10, the deed-consequence nexus in v. 10 , and a generalisation to include all humanity in v. 2. Beat Weber, Werkbuch Psalmen I: Die Psalmen 1 bis 72 (Stuttgart: Kohlhammer, 2001), 159 also notes an acrostic tendency (eight cola begin with $\mathrm{N}$ ). Wisdom is therefore discernible in vv. 1-2, 6, 8, and 9-11, and "pure" thanksgiving only in 3-5 and 7.

5 Hossfeld and Zenger, Die Psalmen I, 200-201, fail to recognise the intention of the implied author and consequently view vv. 6 and $9-10$ as poorly integrated into the supposed original psalm. Klaus Seybold's masterfully concise exegesis (Klaus Seybold, Die Psalmen, HAT I/15; Tübingen: J.C.B. Mohr, 1996) 133-6 is hampered by his 
thanksgiving psalm with secondary wisdom elements, but as a wisdom teaching psalm replicating elements from a psalm of thanksgiving. ${ }^{6}$ Its purpose was not to give thanks, but to exhort members of the in-group of the implied author to uphold certain views and to encourage them to emulate the actions of the implied author, identified as "David" in the heading.

One may ask how the psalm could be intended to teach if fellow believers were addressed directly only once, right at the end (v. 11)? The argument in this article is that Ps 32 is a social and rhetorical composition with literary, theological and social aims. ${ }^{7}$ The experience of the implied author, "David," that his life ebbed away when he stubbornly refused to confess his sins (vv. 3-4), is retold in the psalm as a way of encouraging members of the in-group to avoid his mistake. He tried to "hide" or "cover" his sins from YHWH (v. 5) but suffered as a result (vv. 3-4). When he abandoned his attempt, things worked out well for him (v. 5). This experience is implicitly, but also explicitly, used to give teaching to members of the in-group: At first there is a subtle call to them to pray to Yahweh while he may still be found (v. 6a), and this is then followed by aphorisms (vv. 6bc; 10) and thanksgiving (v. 7) which emphasise the different outcomes of the lives of upright, righteous people in comparison to wicked people (v. 10). Psalm 32 thus serves the same purpose as Ps 1, namely, to define the different destinations of the righteous and the wicked. This is done to advocate certain values and warn against others. A climax is reached when Yahweh himself is introduced as a speaker, addressing the implied author and exhorting him to be wise rather than stubborn like a pack animal (vv. 8-9). This exhortation from YHWH was directed at the audience who would identify with the implied author.

Since wisdom teaching is present in all sections of a carefully constructed psalm, ${ }^{8}$ it is not true that the wisdom parts are more heterogeneous, less poetic or somehow irrelevant to the situation of the psalm as some investigators suggest. ${ }^{9}$ The objective of this article is, therefore, to determine what specific social and cultural context the psalm reflects, what problem or problems the

fragmentation of the psalm into a presupposed original "Dankpsalm" consisting of three strophes.

6 Cf. Phil J. Botha, "Psalm 32 as a wisdom intertext," HTS Teologiese Studies/Theological Studies 70(1) (2014): 1-9, art. \#2710, 9 pages, 1-9.

7 According to Elliott, "Perspective," 1, every biblical writing was designed as a means of social communication and interaction aimed at prompting social action on the part of its targeted audience. The genre, content, structure and meaning of biblical texts are all socially and culturally determined and social-scientific criticism is needed to uncover the dynamics of social relations, core cultural values, typical attitudes and perspectives, and prominent social-cultural behavioural scripts.

8 Cf. J. Henk Potgieter, "The structure and homogeneity of Psalm 32," HTS Teologiese Studies/Theological Studies 70(1) (2014): 1-6. Art. \#2725, 1-6.

9 For example, Hossfeld \& Zenger, Die Psalmen I, 200-1. 
implied author wanted to address, and how it was designed to be an effective instrument in bringing about changes in conduct or belief in the implied audience.

Temple theology does play a role in Ps 32, but if the presumed Sitz-imLeben of a Todah is prevented from obscuring the analysis, its purpose to instruct can be detected with a fair measure of certainty. This objective is already reflected in its heading, which describes it as a "Maskil of David." 10 The implication is that "David" provided wise teaching to Israel from his own experience. Although Solomon is regarded as the father of wisdom in Israel, David could assume a sapiential role in addition to his priestly and prophetic roles. The objective to teach is further also evident from the double beatitude (אשרי) with which the psalm begins, a wisdom characteristic which here praises the person "whose transgression is forgiven" and "against whom YHWH counts no iniquity" (vv. 1bc-2ab). This opening strophe (A) possibly gives an indication that Proverbs 28:13-14, with which the whole psalm seems to have connections, ${ }^{11}$ was considered by the author as authoritative material for his audience. ${ }^{12}$ The truth of the aphorism in Proverbs 28:13-14 is demonstrated in strophe B in the form of a confession about the implied author's personal experience of its soundness. Stubborn resistance against YHWH's discipline, the problem addressed by Proverbs 28:13-14, is dealt with in greater detail in the second stanza of the psalm where YHWH is introduced as authoritative speaker (strophe E) ${ }^{13}$ This section is usually understood from a historical-critical point of view as an "oracle" by YHWH within a cultic context, ${ }^{14}$ but it functions rather as a divine apostrophe, a technique of the author to address the audience directly and authoritatively. A jussive form (v. 6) ${ }^{15}$ imperatives (v. 11), polarisation of the fate of the wicked and the righteous (vv. 10-11), and ominous references to disaster and chaos in the lives of members of the out-group (vv. 6,10) are further

10 Derived from שכל I, it would point to an instructive text (Seybold, Die Psalmen, 134). This is confirmed by the same stem being used in v. 8 .

11 Bernard Gosse, L'influence du livre des Proverbes sur les rédactions bibliques à l'époque perse (Paris: Gabalda, 2008), 67 has pointed out the similarity with Proverbs 28:13, but the present author has argued that Proverbs 28:13-14 (which constitutes a unit, bound together through chiasmus) should be considered as a donor text. William McKane, Proverbs: A new approach (OTL; London: SCM Press, 1970), 628 has noted that the only two texts in the Hebrew Bible where ידה in the hip 'il is used with פשע for confession of sins, is Prov 28:13 and Ps 32:5.

12 The title of the psalm, which attributes it to "David," clashes with the idea that it made use of Proverbs 28. This is the case, however, in many psalms which display dependence on Proverbs. It is possibly for this reason that the allusions are sometimes vague, although the similarities are conspicuous in this case.

13 Seybold, Die Psalmen, 136 mistakenly assumes that this is the personal advice of the psalmist which then develops into teaching about the way of penance.

14 Hossfeld and Zenger, Die Psalmen I, 204.

15 The form יתפלל could also be an imperfect but is usually understood as a jussive. 
used to persuade the audience to accept YHWH's discipline within an intimate and happy setting of protection and celebration. The text as well as a possible exposition of how the author intended to design its form is given below ${ }^{16}$ before the investigation proceeds to an ideological and social-scientific analysis.

\section{B THE TEXT AND POSSIBLE STRUCTURE OF PSALM 32}

\begin{tabular}{|c|c|c|c|c|}
\hline & & & לְדָדוֹד מַשְְְׁכיל & ${ }^{1}$ A Maskil of David. \\
\hline \multirow[t]{12}{*}{ I } & A & $1 \mathrm{~b}$ & 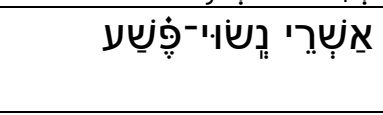 & $\begin{array}{l}\text { Blessed is the one whose } \\
\text { transgression is forgiven, }\end{array}$ \\
\hline & & $\mathrm{c}$ & 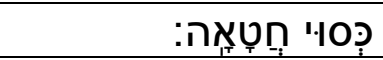 & whose $\sin$ is covered \\
\hline & & $2 \mathrm{a}$ & 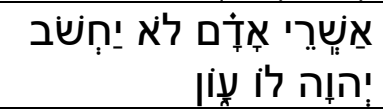 & $\begin{array}{l}{ }^{2} \text { Blessed is the person against whom } \\
\text { YHwH counts no iniquity, }\end{array}$ \\
\hline & & $\mathrm{b}$ & 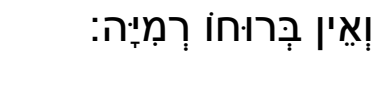 & $\begin{array}{l}\text { and in whose spirit there is no } \\
\text { deception. }\end{array}$ \\
\hline & B & $3 a$ & 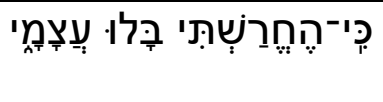 & $\begin{array}{l}3 \text { "When I kept silent, my bones } \\
\text { became brittle }\end{array}$ \\
\hline & & $\mathrm{b}$ & 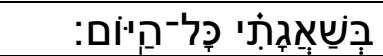 & through my groaning all day long. \\
\hline & & $4 \mathrm{a}$ & 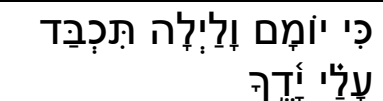 & $\begin{array}{l}{ }^{4} \text { For day and night your hand was } \\
\text { heavy upon me; }\end{array}$ \\
\hline & & $\mathrm{b}$ & 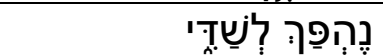 & my marrow was changed \\
\hline & & $\mathrm{c}$ & 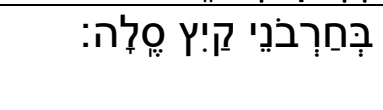 & $\begin{array}{l}\text { (as) by the dry heat of summer. } \\
\text { Selah }\end{array}$ \\
\hline & $\mathrm{C}$ & $5 \mathrm{a}$ & 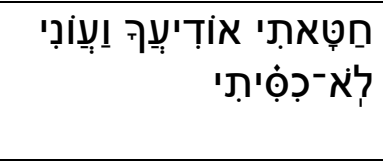 & $\begin{array}{l}5 \text { I acknowledged my sin to you, and } \\
\text { I did not cover my iniquity (any } \\
\text { longer); }\end{array}$ \\
\hline & & $\mathrm{b}$ & 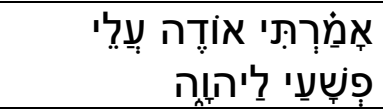 & $\begin{array}{l}\text { I said, 'I will confess my, } \\
\text { transgressions to YHWH,' }\end{array}$ \\
\hline & & $\mathrm{c}$ & 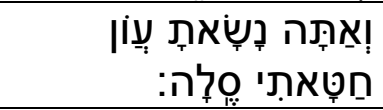 & $\begin{array}{l}\text { and you forgave the iniquity of my } \\
\text { sin." Selah }\end{array}$ \\
\hline \multirow[t]{8}{*}{ II } & $\begin{array}{l}\mathrm{D} \\
\left(\mathrm{C}^{\prime}\right)\end{array}$ & $6 a$ & 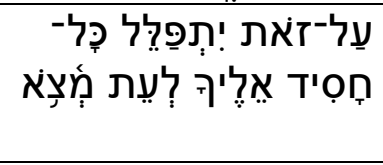 & $\begin{array}{l}{ }^{6} \text { Therefore, let everyone who is } \\
\text { godly offer prayer to you at a time } \\
\text { when you may be found; }\end{array}$ \\
\hline & & $\mathrm{b}$ & 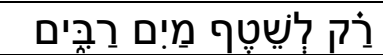 & surely in the rush of great waters, \\
\hline & & c & 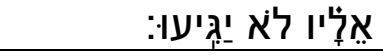 & they shall not reach him. \\
\hline & & $7 \mathrm{a}$ & 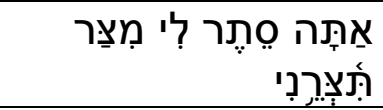 & $\begin{array}{l}{ }^{7} \text { You are a hiding place for me; you } \\
\text { preserve me from trouble; }\end{array}$ \\
\hline & & $\mathrm{b}$ & 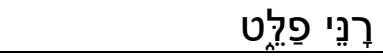 & with shouts of deliverance \\
\hline & & c & 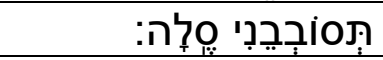 & you surround me. Selah \\
\hline & $\begin{array}{l}\mathrm{E} \\
\left(\mathrm{B}^{\prime}\right)\end{array}$ & $8 \mathrm{a}$ & 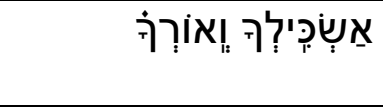 & 8 "I will instruct you and teach you \\
\hline & & $\mathrm{b}$ & 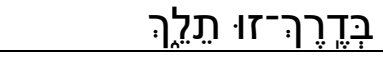 & in the way you should go; \\
\hline
\end{tabular}

16 Small changes are made to Potgieter's exposition (cf. Potgieter, "Psalm 32," 3). 
Botha, "Psalm 32," OTE 32/1 (2019): 12-31

\begin{tabular}{|c|c|c|c|}
\hline & $\mathrm{c}$ & 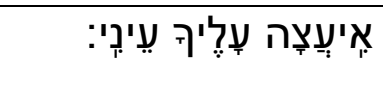 & $\begin{array}{l}\text { I will counsel you with my eye upon } \\
\text { you. }\end{array}$ \\
\hline & $9 \mathrm{a}$ & 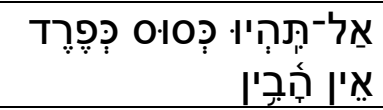 & $\begin{array}{l}{ }^{9} \text { Be not like a horse, like a mule, } \\
\text { without understanding, }\end{array}$ \\
\hline & $\mathrm{b}$ & 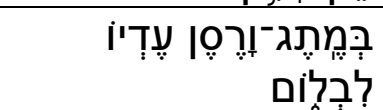 & $\begin{array}{l}\text { which with bit and bridle as its } \\
\text { utensils must be restrained, }\end{array}$ \\
\hline & $\mathrm{c}$ & 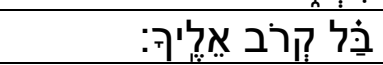 & or it will not come near to you." \\
\hline $\begin{array}{l}\mathrm{F} \\
\left(\mathrm{A}^{\prime}\right)\end{array}$ & $10 \mathrm{a}$ & 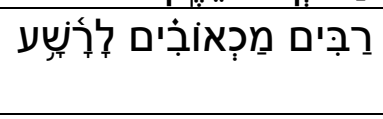 & $\begin{array}{l}{ }^{10} \text { Many are the sorrows of the } \\
\text { wicked, }\end{array}$ \\
\hline & $\mathrm{b}$ & 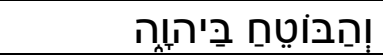 & but the one who trusts in $\mathrm{YHWH}$, \\
\hline & $\mathrm{c}$ & 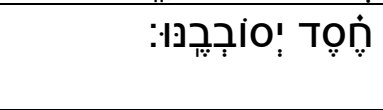 & $\begin{array}{l}\text { with steadfast love he surrounds } \\
\text { him. }\end{array}$ \\
\hline & $11 \mathrm{a}$ & 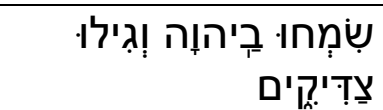 & $\begin{array}{l}{ }^{11} \text { Be glad in } \mathrm{YHWH} \text {, and rejoice, } \mathrm{O} \\
\text { righteous, }\end{array}$ \\
\hline & $\mathrm{b}$ & 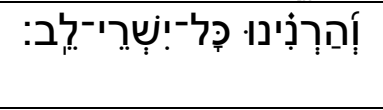 & $\begin{array}{l}\text { and shout for joy, all you upright in } \\
\text { heart! }\end{array}$ \\
\hline
\end{tabular}

\section{Notes on the translation:}

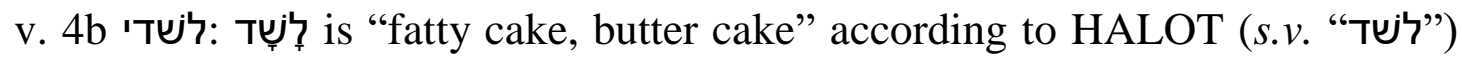
and the suggestion of this dictionary is to change the word to 'לשנ ("my tongue"). חָרְבוֹן in the prepositional phrase of the third stich (v. 4c), however, is "dry heat," and the meaning must be parallel to the psalmist's "bones" "becoming brittle" in verse 3. It is consequently understood as the "marrow" or "fat," a metaphor for the "strength" of the psalmist, drying up (as) in the heat of summer. The previous entry in HALOT (entry 4700) is a hypothetical form לשד from Arabic lasada to "suck, absorb."

v. 7b רני is understood as a plural construct of derived from the root רנן, thus "songs of liberation" (cf. HALOT, s.v. "רן"). Cf. also the occurrence of the same stem in v. 11.

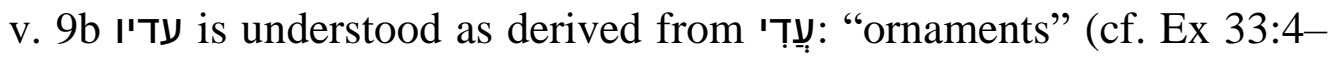
6), thus "with bit and bridle as its utensils to restrain."

The coherence and structure of Ps 32 were described by Potgieter. ${ }^{17}$ The six strophes are uniformly distributed between its two stanzas and arranged in chiastic order (A corresponds to F, B to E, and C to D). ${ }^{18}$ Strophe A is a double beatitude pronouncing a blessing on the one whose transgression is forgiven; whose sin is covered; against whom YHWH counts no iniquity; and in whose

17 Potgieter, "Psalm 32," 1-6.

18 Already suggested by many others, e.g. Weber, Werkbuch Psalmen I, 158 and Pieter van der Lugt, Cantos and Strophes in Biblical Hebrew Poetry with special reference to the First Book of the Psalter (OTS 53; Leiden, Boston: Brill, 2006), 325. 
spirit there is no deception. Strophe B recounts in the first person singular the implied author's wasting away because YHWH's hand "was heavy" upon him when he kept silent. But in strophe $\mathrm{C}$, the implied author hints at this state of suffering as having ended when he acknowledged his sin and (no longer) concealed his iniquity - he confessed his "sin," "iniquity" and "transgressions" and YHWH forgave the "iniquity of" his "sins." Hossfeld and Zenger note the inclusion formed by the repetition of "iniquity" (עון) and "sin" (חטאה) and describe the expression "the iniquity of my sin" as a "plerophore" construction (thus emphasising full measure). ${ }^{19}$ It can also be understood as hendiadys (thus "my sinful transgression"). What is noteworthy is that the three words "sin," "transgression," and "guilt" are all used in verse 5ab where confession is described, and two of these are repeated in the statement about forgiveness being given. This signifies the completeness of the psalmist's confession and of his forgiveness. The verbs נשא and used in the beginning are also repeated at the end of the stanza (vv.1bc and 5ac), creating inclusio in the unit and identifying the supplicant as one of the "blessed persons."

Stanza II also has inclusion: The adjective רבים of verse 6b is repeated in the same form in verse 10a; the verb סבב of verse 7c is repeated in verse 10c; the joyous shouts of verse 7b (רני) return as a verb in verse 11b (הרנינו) and the idea of "trouble" (צר, v. 7a) features again in the word "sorrows" (מכאבים) in verse 10a. Strophe D can be interpreted as the logical consequence of strophe C, since it begins with "therefore" (אל־זאת) and continues the direct address to YHWH, using the positive experience the implied author ("David") had as a reason for exhorting "everyone who is godly" to pray to YHWH timeously. Strophe E (B') is a first-person monologue like strophes B and C, but the speaker in this instance is YHWH, and he is responding to the first-person confession of the implied author in strophe B. The implied author referred to YHWH's "hand" which was heavy upon him (עלי) in strophe B (v. 4a). In contrast to this, YHWH announces in strophe E that he would rather keep his "eye" upon (עליך) the psalmist (v. 8c). Strophe F (A') finally ends on a positive and joyous note, reflecting again the blessings pronounced in strophe $\mathrm{A}$. The alliteration and rhyme of אשרי in the beginning of the psalm (vv. 1b-2a) with ישרי־לב at the end of the psalm (v. 11b) form inclusion and identify the "blessed" person as the one who is "upright in heart." 20

\section{THE TEXTUAL STRATEGY SUGGESTED BY THE TEXT OF PS 32}

Instead of a presumed cultic situation, namely a ceremony of thanksgiving after the suppliant has been healed of illness, the contents and form of the psalm should guide the interpretation. These characteristics define its "ideology."

19 Hossfeld and Zenger, Die Psalmen I, 200.

20 Also noted by Weber, Werkbuch Psalmen I, 159. 
Ideology in the sense it is used here refers to the integrated system of beliefs, perspectives, assumptions, and values that contain the most important criteria for interpreting the social reality of the group of people who produced the text and integrated it into the Psalter at this particular place. ${ }^{21}$ The implied author and the implied audience shared a number of "root metaphors" which gave meaning to their perception of reality. ${ }^{22}$ The most important of these metaphorical representations which define the epistemology of the psalm will now be discussed.

\section{Temple theology}

As was already acknowledged, the temple does play a role in Ps 32. According to this metaphoric complex, someone who suffers from social, physical or psychological needs or distress could go to the temple to seek an audience with YHWH who was imagined to be like a king in his throne-room. That person's supplication in or at the temple, but even while far away from the temple, could be accompanied by a vow. ${ }^{23}$ The supplication would possibly be heard, favourably accepted and answered, and the individual would thus experience rescue, salvation or some kind of help. This then obliged that person to repay any vows, to give thanks to YHWH and to give witness about his or her salvation, sharing in a joyful celebration of the fullness of life granted by YHWH together with the community of worshippers. While the suppliant would feel off-centre while in distress, access to the presence and help of YHWH would move the suppliant to be at centre, in the presence of YHWH. Because YHWH was seen to be present in the temple, the temple was viewed as a place of refuge, protection, and safety at the centre of the world where one could share in the fullness of life provided by YHWH. ${ }^{24}$ Although the Solomonic temple did not exist in David's

21 Cf. the definition of Elliott, What is social-scientific criticism?, 130, of ideology and its connection with theology. His description is abbreviated here.

22 This refers to the metaphors that helped people to understand conceptual domains by taking recourse to domains of human experience. Such conceptual metaphors formed coherent cognitive models - "complex gestalt structures of organised knowledge as pragmatic simplifications of an even more complex reality." Cf. Olaf Jäkel, "Hypotheses revisited: The cognitive theory of metaphor applied to religious texts," Metaphorik.de 02 (2002): 20-42, 21.

23 Cf. the psychological distress experienced by Hannah and her praying at the sanctuary, also making a vow in 1 Sam 1:6-11.

24 Cf. Friedhelm Hartenstein's summary description of his view of the metaphoric understanding of YHWH's protective throne sphere and the audience that takes place there as depicted in Pss 5 and 27: Friedhelm Hartenstein, Das Angesicht JHWHs: Studien zu seinem höfischen und kultischen Bedeutungshintergrund in den Psalmen und in Exodus 32-34 (Tübingen: Mohr Siebeck, 2008), 205-9. The terminology derived from an audience at a royal court included semantic fields of words focused on the expectation of the protection associated with the granting of an audience; salvation 
time, use of this representation is nevertheless made in many psalms which are linked to his name and which speak of the "sanctuary" (קדשe), "his holy hill" or "the holy temple" in Jerusalem.

The suppliant of Ps 32, thought to be "David," is presented in the psalm as a person who tried to hide his sins and because of that suffered bodily (cf. "my bones," "my strength" in vv. 3-4) but also psychologically ("your hand was heavy upon me," v. 4). The description in verses 3-4 suggests that his experience resembles that of someone who suffered from fever (cf. vv. 3a and 4c). It was as if YHWH's hand pressed down heavily upon him (v. 4), he groaned all day long (v. 3b), his bones felt as if they were becoming brittle (v. 3a) and his inner strength was drained (v. 4b) like someone who suffers from heat exhaustion on a summer's day (v. 4c). Fortunately, he came to his senses and confessed his sins. YHWH forgave the iniquity of his sins and he could now present a Todah to YHWH. ${ }^{25}$ As part of his thanksgiving, he advises fellow believers to pray to YHWH at the right time (v. 6a) and acknowledges that YHWH is a hiding place for him, preserving him from trouble (v. 7a). ${ }^{26}$ YHWH's protection is metaphorically portrayed as his "surrounding" the psalmist with "shouts of deliverance" (v. 7c) and here, after having arrived at centre in the temple, he is also "surrounded" by YHWH's "steadfast love" (v. 10c). This replicates the protection sometimes accorded to a worshipper in the Psalter described as YHWH using the large shield for protection around the suppliant. ${ }^{27}$ The in-group is also called upon to rejoice with the suppliant (v. 11) in typical Todah fashion.

\section{Sin, illness and prosperity}

One of the beliefs shared by the people who produced Ps 32 is that sin which is not confessed but is hidden, "concealed," can cause illness. It is as if guilt is experienced as a disruptive force affecting the physical existence of that person, draining away his or her life. ${ }^{28}$ The implied author refers to his "bones" becoming brittle. He "groaned" all day long, and his "strength" was "changed" (thus drained or dried up), as if by the dry heat of summer. His experience seems comparable to that of one who suffers from dehydration or fever, feeling weaker

by YHWH; participation in the fullness of life in YHWH's presence; and the exultant response to it.

25 The connection of Ps 31 with Ps 32 is that of a lament and a psalm of thanksgiving. Ps 31:11 also speaks of illness, inter alia the "bones" of the psalmist "wasting away" (כלה). See Gianni Barbiero, Das erste Psalmenbuch als Einheit: eine synchrone Analyse von Psalm 1-41 (ÖBS 16; Frankfurt am Main: Europäischer Verlag der Wissenschaften, 1999), 424-30 for a description of the connections.

26 Cf. the specific association of "hiding place" (רת) with the temple in Ps 27:5.

27 Pss 3:3; 7:11; 18:2, 30, 35; 28:7; 30:20; etc.

28 Kraus, Psalmen, 403. Craigie and Tate, Psalms 1-50, 2004, 266 reject the idea of psychosomatic illness as a bodily reaction to the internally contained conflicts of guilt. They (p. 267) interpret the words in a more general poetic sense. 
and weaker, unable to get up, as if the hand of YHWH were pressing down heavily upon him (v. 4a). A similar description is also found in Ps 31:11, a verse that has editorial connections to Ps 32:3-4. There the suppliant says, "For my life fades away in agony, and my years in sighing, my strength fails through my iniquity, and my bones waste away." Different words are used for "strength," but "bones" are also referred to, also in a similar description parallel to "strength."

Verse 4 does not declare bluntly that YHWH was punishing the implied author, ${ }^{29}$ but strophe E (v. 9) does suggest that the psalmist was acting "without understanding" during this period. He did not realise what YHWH's purpose was with him and consequently was like a horse or a mule which must be restrained with bit and bridle to be "brought near" its handler. On the other hand, when the psalmist gave in and confessed, YHWH forgave his sins. He experienced this forgiving as a weight being lifted from him (שن, 1b, 5c). Kraus ${ }^{30}$ notes that it seems that liberation from sins was more important to the psalmist than his healing, since his healing is not mentioned, but it is perhaps more accurate to say that, for the psalmist, forgiveness constituted an important part of restoration to proper human well-being and thus formed an important part of healing. ${ }^{31}$ The psalm seems to address the negative effect caused by a wrong attitude towards YHWH - an attitude of rebelliousness that affects all aspects of one's being - but the focus is rather on the possibility of a restored relationship with YHWH, not on the causality of $\sin .{ }^{32}$

\section{Wisdom epistemology}

Although Hartenstein ${ }^{33}$ interprets the guidance of YHWH (his "teaching" and "leading" the psalmist on a "level path") in Ps 27:11 also as part of the metaphorical complex of a temple audience with YHWH and as a "reflex of the institutional background of juridical decisions at the sanctuary," ${ }^{34}$ there is no

29 Weber, Werkbuch Psalmen I, 158 describes the implied author's suffering as psychosomatic discomforts which were understood to be caused by YHWH himself.

30 Kraus, Psalmen, 404-5.

31 For people of the Bible, illness constituted more than what science would describe as disease, while restoration from the "socially disvalued" state of illness constituted healing. Cf. John Pilch, J., art. s.v. "Healing," pages 102-6 in John J. Pilch, and Bruce J. Malina, (eds.), Handbook of Biblical Social Values (Peabody: Hendrickson, 1998), $102-3$.

32 Kraus, Psalmen, 407.

33 Hartenstein, Das Angesicht JHWHs, 81.

34 He says (Hartenstein, Das Angesicht JHWHs, 81) that one cannot see the reference to guidance on a road only as an expression of chokmatic imagery, but has to understand it as "der Reflex eines institutionellen Hintergrundes (von Rechtsentscheiden am Heiligtum) ..." Even in the case of Ps 27:11, he is mistaken with this identification. Guidance on the road of life is a wisdom concept that was introduced in many psalms which also reflected a temple theology. 
doubt that the author of Ps 32 has combined the temple-theological milieu with wisdom epistemology and that the latter dominates the psalm as a whole. The clearest example of wisdom teaching is found in verse 8, where YHWH is represented as a guide on the road of life, ${ }^{35}$ but more than this is involved. It has been suggested that the teaching found in Proverbs 28:13-14 is reflected in both stanzas of Ps $32 .{ }^{36}$ These two verses in Proverbs 28 state:

\begin{tabular}{|c|c|}
\hline 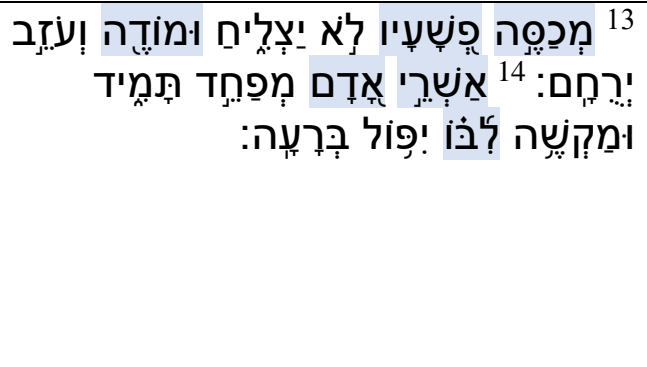 & $\begin{array}{l}{ }^{13} \text { Whoever conceals his } \\
\text { transgressions will not prosper, but he } \\
\text { who confesses and forsakes them will } \\
\text { obtain mercy. }{ }^{14} \text { Blessed is the one } \\
\text { who fears (YHWH) always, but } \\
\text { whoever hardens his heart will fall } \\
\text { into calamity. }\end{array}$ \\
\hline
\end{tabular}

The highlighted Hebrew words are all found in a similar meaning in Ps 32, ${ }^{37}$ whilst the concepts of צל (hip il, "to be prosperous"), קשה (in the pi 'el, "to harden") and רעה ("calamity") are also reflected in the psalm as well. The interjection אשרי (which occurs twice in Ps 32) is used in parallel with the verb צלח in these two verses from Proverbs, so the idea of "prospering" is implied in the psalm as well through repetition of אשרי; 38 the idea of "hardening" one's heart is reflected in Ps 32 when YHWH tells the suppliant not to be "like a horse or a mule, without understanding" (v. 9a); ${ }^{39}$ and the idea of disaster or calamity is demonstrated in the first stanza through the suffering of the psalmist and in the

35 Cf. the analysis (using English Bible translations) by Jäkel ("Cognitive theory of metaphor," 25-34) of the journey metaphor in a religious context. This involves (inter alia) the two ways of life, the two kinds of travellers, and God's role as observer and guide.

36 Botha, "Psalm 32," 1-9.

37 The verb הos is first used as antonym through employing the qal passive participle ("covered," thus forgiven) in Ps 32:1 whereas Proverbs 28:13 has the pi 'el participle ("concealing," thus trying to hide). In Ps 32:5a the psalmist says that he did not "cover up" his iniquity (any longer), using the pi 'el perfect in the same meaning as in Prov 28:13.

38 Cf. the parallel use of צלח וin Ps 1:1 and 3 as well.

39 A horse, a donkey, and a fool are mentioned together in Proverbs 26:3 as lacking in understanding and therefore in need of (respectively) a whip, a bridle, and a rod. In Proverbs 29:17, it is said that a slave also cannot be disciplined by words (alone), since he might understand, but will not respond. These proverbs demonstrate the authoritarian society of the ancient Near East where authority was invariably sanctioned by force. Cf. Bruce J. Malina, art. s.v. "Authoritarianism," pages 12-19 in Pilch, John J. and Malina, Bruce J. (eds.), Handbook of Biblical Social Values (Peabody: Hendrickson, 1998), 12. 
second stanza through the danger in "the rush of great waters" (v. 6), ${ }^{40}$ the "trouble" (צר) from which YHWH preserves the suppliant in verse 7a, and the many "sorrows" (מכאבים) of the wicked in verse 10a. Psalm 32 thus seems to provide a free explication of these two verses from Proverbs and its message is that the one who fears YHWH ${ }^{41}$ and subjects himself to YHWH's (kind-hearted) discipline by confessing his or her sins and abandoning them, will obtain mercy and thus be blessed; but the one who stubbornly tries to resist YHWH's discipline could possibly expect to suffer corporeally and spiritually or to be struck by some kind of disaster (a flood, trouble, or sorrows). The idea of "obtaining mercy" in Proverbs 28:13 is represented in Ps 32 through YHWH's taking away the guilt of the author's transgression (v. 5) and through the suppliant's being "surrounded" by (YHWH's) "steadfast love" in verse 10.

A positive attitude towards the "discipline" of YHWH as a loving father is also advocated in Proverbs 3:11-12. ${ }^{42}$ YHWH's offer to "instruct" (שכל hip 'il) and "teach" (ירה hip 'il) the psalmist in the "way" (דרך) he should go, and to "counsel" him (ירה) "qal), echoes the offer of the wisdom teacher to teach "ירץ " hip 'il, דרך hip 'il) his student the way of wisdom in Proverbs 4:11. This "root metaphor" of ancient wisdom was reinterpreted already in Proverbs so that YHWH came to assume the function previously undertaken by the wisdom teacher. ${ }^{43}$ This is the representation employed in Ps 32:8-9 as well.

A comparison with Proverbs 3:5-8 is equally enlightening. This pericope encourages the student of wisdom to "trust" (בטח) (cf. Ps 32:10b) in YHWH with all his heart and not lean on his own "understanding" (בינה) (cf. Ps 32:9a, בין (בינה) hip 'il); to acknowledge him in all his ways so that YHWH can make his "paths" straight; to not be wise in his own eyes, but to fear (ירא) YHWH and turn away from "evil" (רע), because that will provide healing to his flesh and bring refreshment to his "bones" (עצם). "Trust" (בטח) in YHWH is also advocated in Ps 32:10, and it is certainly so that the suppliant's "bones" (also עצם) (cf. Ps $32: 3$ ) needed refreshment when he kept silent and they became brittle. Proverbs 3:23-26 goes on to promise the student of wisdom who has acquired insight (תבונה, 3:13), a safe journey, sweet sleep, and not having to fear "sudden terror" (פחד פתאם) or the "ruin" (שואה) of the wicked when it comes (3:25). The psalm certainly seems to reflect the images and teaching of Proverbs.

40 Kraus, Psalmen, 405 refers to the metaphor of מים רבים in Ps 18:5; Isa 8:7-8; 17:12; and 23:3. The representation is that of a sudden flood in a wadi.

41 Ps 36:2 says that transgression (פשע) extends to the core of the wicked because he has no "fear of God" (פחד אלהים).

42 "My son, do not despise YHWH's discipline or loathe his reproof, for YHWH disciplines those he loves, as a father the son in whom he delights."

43 Norman C. Habel, "The symbolism of wisdom in Proverbs 1-9," Interpretation 26 (1972): 131-57, 144. 
Psalm 32 displays many similarities with Ps 1 and the two share the same wisdom epistemology. ${ }^{44}$ As Ps 1 alludes (inter alia) to Proverbs 1:10-19, so Ps 32 seems to allude to Proverbs 28:13-14. Psalm 1 begins with a beatitude (אשרי) on the righteous (1:1), without identifying the righteous by name, but by describing such a person's actions with three relative sentences formulated negatively (1:1) and two relative sentences formulated positively (1:2). Psalm 32 begins with a double beatitude (also אשרי) combined with four relative sentences, two formulated positively (32:1) and two negatively (32:2). As Ps 1 reveals the identity of the "blessed" person (האיש) at its end as the "righteous" (צדיק) (1:5-6), so Ps 32 reveals the identity of the "blessed" person (אדם) ase one who trusts in YHWH (בטח ביהוה), the "righteous" (צדיקים) and the "upright in heart" (ישרי לב) at its end (32:10-11). The two groups of people are contrasted in both psalms through their being protected or unprotected: YHWH "knows the way" of the righteous (1:6) and "counsels them with his eye upon them" (32:8); but the "wicked" (רשעע) will have a disastrous end (1:6) and many sorrows (32:10). When YHWH declares in Ps 32:8 that he wants to "instruct" and "teach" (דרה hip 'il) the psalmist in the "way" (דרך) he should go, there can be little doubt that Ps 32 is a wisdom-Torah psalm similar in construction and intent to Ps $1^{45}$ and Ps $25 .{ }^{46}$ When the implied author of Ps 32 tells about the hand of YHWH resting heavily upon him "day and night," there is the connotation of remorse felt by the psalmist, since the blessed righteous person of Ps 1 was said to meditate on the Torah "day and night" (Ps 1:2). Those who pray to YHWH at the right time and meditate on his Torah continually, experience "success" (צלח hip 'il, Ps 1:3; cf. the contrast with Prov 28:13), not suffering like the psalmist of Ps 32.

\section{The deed-consequence nexus}

The psalm expresses a connection between action and consequence in both stanzas - ignoring the wisdom teaching of Proverbs not to try to hide one's sins

44 Cf. in this regard the comprehensive comparison of Gianni Barbiero, Das erste Psalmenbuch als Einheit, 528-31, who also notes the similarities between his discussion and the similar investigations of Pierre Auffret, "Essai sur la structure littéraire du Psaume 32," VT 38 (1988), 257-85, 278-83 and Matthias Millard, Die Komposition des Psalters: Ein formgeschichtlicher Ansatz (FAT 9; Tübingen: J.C.B. Mohr, 1994), 138.

45 John Kartje, Wisdom epistemology in the Psalter (BZAWissenschaft, 472; Berlin: De Gruyter, 2014), 83 assumes that Ps 1's conceptual metaphors allow little opportunity for a foundational change in the orientation of one's life. I do not agree, since the purpose of Ps 1 is to describe the differences between the righteous and the wicked and thereby to encourage the way of life of the righteous and to warn against the conduct of the wicked. It is designed to effect change in the perspectives and approach to life of people.

46 Cf. also YHWH's "teaching" sinners the "way" in Ps $25: 8$, also in v. 12. Cf. also Ps 27:11. 
(vv. 1-2) led to the psalmist's suffering and his life's ebbing away (vv. 3-4); confession of his sins in contrast led to forgiveness (v. 5) and, by implication, "deliverance" (v. 7b), protection (v. 7a), and "joy" (v. 11b). The author does not state that he became well again, but the talk about deliverance, protection, lack of trouble, and rejoicing in the second stanza implies that complete restoration happened after his period of suffering.

By expressing his theology in the form of a description of the implied author's personal experience of deterioration of strength (vv. 3-5), the author prevents the reader from concluding that certain actions mechanically lead to certain consequences. The experience described in strophe B was the personal experience of the implied author and from this experience he formulates his teaching which confirms the truth of Proverbs 28:13-14. The underlying system of thought basically supports the doctrine of retribution, however, and this can be seen at work in verses 6 and 10. The "rush of great waters" or "rush of many waters" describes a sudden life-threatening situation (cf. Pss 69:1, 3 and 15; 124:4 and 144:7). The description reminds the reader of descriptions of sudden terror overwhelming the wicked. ${ }^{47}$ "Sorrows" (or "pains" or "suffering") can be avoided ${ }^{48}$ and joyful integration into the community of righteous can be achieved by following the teaching of the psalm (vv. 10-11), which echoes the teaching of Proverbs. This teaching is that one should not try to hide transgressions from YHWH and so harbour "deception" in one's "spirit" (v. 2), that one should pray to YHWH at the right time (לעת מצא, cf. the reference to תמיד, "always," in Proverbs 28:14), ${ }^{49}$ that one should not react stubbornly to the training and guidance of YHWH, and that one should trust (בטח) in YHWH and not in one's own wisdom (vv. 9-10; cf. Prov 3:5).

In the middle strophe of stanza II, the psalmist lets YHwH speak. His words entail a friendly invitation not to be unwise, not to resist discipline, but to act like a good student of wisdom or a wise Yahwist. The comparison between being wise (ב hip $^{\prime} \mathrm{il}$ ) and acting like an untrained horse or mule is also based on wisdom teaching..$^{50}$ In this psalm, the invitation expresses a special relationship between YHWH and his followers, with YHWH acting as a guide on the road of

47 Proverbs 3:25 promises, within a context of complete trust in YHWH (Prov 3:5), that one who practices wisdom do not need to be afraid of "sudden terror or of the ruin of the wicked, when it comes."

48 Cf. the connection between sins (חטאות), guilt (עון), and pain (מכאב) as punishment expressed in Jer 30:15.

49 Kraus, Psalmen, 404 refers to the light provided by Isa 49:8 and 55:6 on this verse - he should be sought in a favourable time and a time while he may be found and while he is near.

50 Cf. Prov 26:3, "A whip for the horse, a bridle for the donkey, and a rod for the back of fools." 
life, keeping his eye (v. 8) upon the faithful worshipper (TOn) instead of laying a "heavy" hand on him (v. 4).

Practicing this wisdom ensures a happy life and protects one against disaster, trouble, and sorrows, but it also results in happy integration into a community of believers (vv. 7, 11). At the time when the psalm was composed and/or inserted into the First Davidic Psalter, illness, calamity, sorrows, and isolation from the community can therefore be listed as possible problems some members of the in-group experienced (or feared), therefore fear of these things could be used to support a certain religious epistemology. Part of that teaching was a mild form of the dogma of retribution and a rejection of attempts to be secretive, deceptive, rebellious or insincere towards YHWH, since this was characteristic of the wicked. ${ }^{51}$

\section{A DESCRIPTION OF THE IN-GROUP AT WORK IN PS 32}

Psalm 32 begins with statements about being blessed which could refer to any human being: Two passive participles are used to construct two relative sentences referring to "the one whose transgression is forgiven" and "whose sin is covered." In verse 2, this is followed up with a similar statement about "a person" who is blessed (אשרי אדם), very similar to Ps 1's beginning statement about "the man" who is blessed (אשרי האיש), but more generic. This has been described as a characteristic of the "generalising" tendency of wisdom, but here it is possibly rather a case of delayed identification of the in-group, a strategy to get the attention of the reader or listener. As in the case of Ps 1, the people to whom this description refers would soon recognise themselves as the subjects of these macarisms. While the possible connections with Proverbs 3:13 and 28:1213 would dawn upon the informed reader when the combination אשרי אדם is used in verse 2 , the identification would be confirmed. ${ }^{52}$

Apart from the psalmist referring to himself in verses 3-5 (an identification which would be interpreted as a testimony of "David"), the first reference to the in-group is found in verse 6 with the description "everyone who

51 Retribution in Proverbs is presented sometimes as simply a consequence of certain actions; sometimes the bad things that happen to good people are described as temporary setbacks (Proverbs 24:16); while sometimes it is stated more openly that YHWH will punish wickedness. This implies that retribution does not happen "mechanically," but that YHWH actively participates in the affairs of humanity in conjunction with human responsibility. Cf. Tremper III. Longman, art. s.v. "Proverbs I: Book of," pages 539-52 in Tremper Longman III and Peter Enns (eds.), Dictionary of the Old Testament: Wisdom Poetry and Writings, A compendium of contemporary biblical scholarship (Downer's Grove: Intervarsity, 2008), 544.

52 The combination אשרי אדם is found only in Pss 32:2, 84:6 and 13, and Prov 3:13, 8:34, and 28:14. The presence of משע , משה 28: hip 'il for "confess" in Prov 28:13 in addition to this formula would be conspicuous to students of wisdom. 
is godly/faithful" (כל־חיח). It is only in verses 10 and 11, and only after the out-group was already described as "the wicked" (רשלע), that the descriptions of the members of the in-group are mentioned in quick succession: "the one who trusts in YHWH" (צבוטח ביהוה), the "righteous" (צדיקים), and "all the upright in heart" (כל־ישרי־לב). This last description forms an inclusio with "everyone who is godly" (כל־חיד) in verse 6, but also (as has been mentioned) through soundplay with the pronouncements of being blessed in verses 1 and 2 .

What do these descriptions tell us about the in-group? They refer to a late post-exilic (possibly Hellenistic) ${ }^{53}$ group of followers of YHWH who were accustomed to or had knowledge of the typical Israelite forms of worship in the Temple, but who had also been schooled in wisdom theology. They accepted the teaching of Torah as authoritative for their lives, but also regarded the pronouncements in Proverbs as pertinent to their situation. That means that some members of the in-group (or people who were on the perimeter of the in-group) were possibly seen by the author of Ps 32 to disregard the teaching of the Torah and of Proverbs. They were seen to be "hardening" (קשה hip il) their hearts (Prov 28:13-14). Consequently, the author of the psalm deemed it necessary to warn the members of the in-group to be careful not to ignore or disregard the discipline of YHWH. In his view, a righteous person was someone who did not try to avoid the eye of YHWH on the road of life, but accepted his involvement with one's personal life and his guidance on the road of life as beneficial to one's well-being and necessary to arrive at the correct destination. ${ }^{54}$ The word T'on should possibly here be understood in the sense in which it was used in the time of the Hasmonean dynasty to indicate the "faithful," those who remained committed to following YHWH in times of trouble. ${ }^{55}$ The wicked are contrasted in verse 10 with "the one who trusts (בטח) in YHWH." Some Jews, it seems, lost faith in YHWH's ability to make any difference in the lives of individuals and of the nation. They did not trust him anymore and consequently did not fear him anymore. ${ }^{56}$ The social and religious situation described in Malachi 3 seems to reflect the conditions experienced in Ps 32 very well: Among the Jews there were people who could be described as sorcerers, adulterers, people who swore falsely, and people who oppressed day-labourers, widows, fatherless children and migrants (Mal 3:5). There were those who said it is useless to serve YHWH,

53 It is noteworthy that the psalm is not present in $4 \mathrm{QPs}^{\mathrm{a}}$ or $4 \mathrm{QPs}^{\mathrm{q}}$ or in the psalm fragments from Nahal Hever (Seybold, Die Psalmen, 134). The term Tron as a description for those who practise ton is found mostly in late chapters of the Hebrew Bible.

54 Ps 33:18-19 helps to explain YHWH's desire to keep his eye on the members of the in-group: His eye is on those who fear him, on those who hope in his steadfast love to deliver their soul from death and keep them alive in famine.

55 In Ps 31:24, the אמונים , the "faithful."

56 Cf. the exhortation in Ps 34:10 to "fear" YHWH, because those who fear him have no lack. 
since the arrogant and evildoers prospered (בנה Ni) even though they put God to the test (Mal 3:14-15). Some of the faithful began to call the arrogant "blessed" - מאשרים. In a situation like that, it was necessary to define clearly who the people were who were blessed - those who really were "אשרי"."

The author of Ps 32 uses enticement as well as deterrence as techniques to convince his audience of the necessity to remain dedicated to YHWH. Enticement is present in the beatitudes in verses 1 and 2 and in the descriptions of a happy life within the community under the protection of YHWH ("a hiding place," "you preserve me from trouble," "with shouts of deliverance you surround me" in v. 7; "with steadfast love he surrounds him," in v. 10; "be glad!," "rejoice!," "shout for joy!" in v. 11). Enticement is also present in the kind invitation of YHWH in verse 8 to accept the instruction and teaching (the Torah) of a divine personal guide, who keeps his eye on the worshipper and cares for him or her.

The threats are contained in the donor text in Proverbs 28 which warns about not being "blessed" and not being "successful," since these are called to mind in the beatitude in verses 1 and 2; further also in the description of the personal experience of the implied author ("David") who tried to conceal his transgression and suffered "day and night," a description reminiscent of the meditation of the righteous in Ps 1 (which carried on "day and night") so that it implies that the author of this psalm suffered remorse. It is also present in the advice in verse 6 that the faithful should pray to YHWH at the opportune time, so that disaster would be avoided; in the implied threat that YHWH would use "bit and bridle" if necessary to discipline his followers (v. 9); and in the aphorism that the wicked person has "many sorrows" (v. 10).

The descriptions of the in-group and the out-group used in Ps 32 are often found in Pss 1-41 and this indicates the extent to which the first Davidic Psalter as a composition was purposefully edited to delineate clearly the borders between the in-group and the out-group in post-exilic Israel. Psalm 1 also contrasts the צדיק מרשע; Ps 4 refers to a righteous person as דon like Ps 32, also advising the in-group to trust (בטח) in YHWH; Ps 5 again contrasts the רשע and the צדיק; Ps 9 refers to the רשעע and refers to the in-group as those who know the name of YHWH and trust (בטח) in him; Ps 11 contrasts the רשע with the "upright in heart" and the צדיק; Ps 12 laments the disappearance of the דיד בריק the increase of the רששע; the author of Ps 16 refers to himself as a דיד and says that he "dwells in safety" (שכן לבטח); the author of Ps 26 confesses that he has "trusted" (בטח) in YHWH and distances himself from the רשטע; the author of Ps 28 says that his heart "trusts" (בטח) in YHWH and dissociates himself from the רשעע; the author of Ps 31 confesses that he "trusts" (בטח) in YHWH and asks him to let the רשיק be put the author of Ps 33 again says that the in-group "trusts" (בטח) in YHWH's name and refers to a person from that group as "righteous" (צדיק) and "upright"; Ps 34 again 
repeatedly refers to the צשיקים; and contrasts their fate with that of the רשע and,

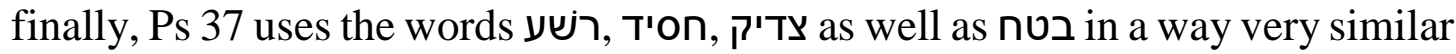
to Ps 32. The distinction of the righteous as the "faithful" who "trusted" in YHWH seems to have been very important.

The personal relationship of a worshipper with YHWH also was a concern of the editors of the first Davidic Psalter. Personal sin, especially as a reason for calamity or illness, seems to have gained in importance as the numbers of the psalms increased. Guilt (עטא (עשון) are referred to specifically in the added section of Ps 18 (vv. 22-28). The theme of sin is also addressed in Pss

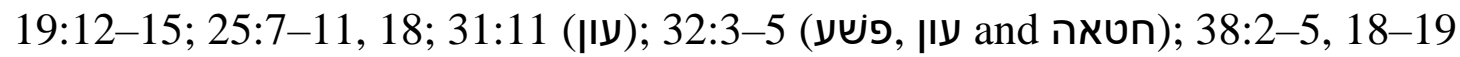

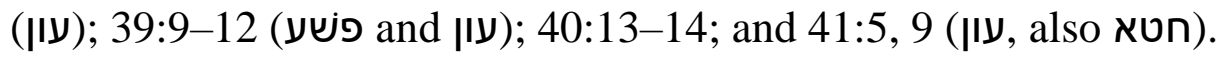

Health, prosperity, safety, and happiness are thus used to motivate certain actions and are described as possible in an open, intimate, and trusting relationship with YHWH, where the worshipper does not act stubbornly, but accepts YHWH's guidance (his discipline; even his seeming hesitance to punish the wicked). "David" is held up as an example of someone who did this. This happy individual is presented as forming part of a community of worshippers who continually pray to YHWH and thank him for deliverance of fellow members of that community, as someone who experienced his steadfast love as a protective shield which gave ample reason for rejoicing.

\section{E CONCLUSION}

Psalm 32 is a coherent and well-integrated argumentative text. It makes use of the Gattung of a psalm of thanksgiving of one who has suffered because of pentup guilt, but in reality, it served the function of exhorting members of the ingroup of the author to accept that those who trust in YHWH by confessing their sins to him are the truly blessed ones in society. "David" as the implied author, relating his experience of suffering during a time of stubbornness, and a direct address by YHWH, are used in the psalm to convince the audience of the truth of the adage that unforgiven sins are harmful to one's health and prosperity. The wisdom forms and theology found throughout the composition suggest that Proverbs had played an important role in the training of the author and it seems to have been his firm belief that an open, personal and close relationship with YHWH as one's guide on the road of life was the only way to ensure protection against disaster, a healthy body and mind, a happy end to one's life, and full integration into the worshipping community of Yahwists.

\section{BIBLIOGRAPHY}

Auffret, Pierre. "Essai sur la structure littéraire du Psaume 32." Vetus Testamentum 38 (1988): 257-85. 
Barbiero, Gianni. Das erste Psalmenbuch als Einheit, eine synchrone Analyse von Psalm 1-41. Österreichische Biblische Studien 16. Frankfurt am Main: Europäischer Verlag der Wissenschaften, 1999.

Botha, Phil J. "Psalm 32 as a wisdom intertext." HTS Teologiese Studies/Theological Studies 70(1) (2014): 1-9, art. \#2710. http://doi.org/10.4102/hts.v70i1.2710.

Craigie, Peter C. and Tate, Marvin E. Psalms 1-50: With 2004 supplement by Marvin E. Tate. Word Biblical Commentary. Nashville: Thomas Nelson, 2004.

Elliott, John H. What is social-scientific criticism? Guides to biblical scholarship, New Testament Series. Minneapolis: Fortress, 1993.

Elliott, John H. "Social-scientific criticism: Perspective, process and payoff: Evil eye accusation at Galatia as illustration of the method." HTS Teologiese Studies / Theological Studies 67 (2011): 1-10. https://doi.org/10.4102/hts.v67i1.858.

Gosse, Bernard. L'influence du livre des Proverbes sur les rédactions bibliques à l'époque perse. Paris: Gabalda, 2008.

Gunkel, Herman. Die Psalmen, übersetzt und erklärt. 6. Auflage. Göttingen: Vandenhoeck \& Ruprecht, 1986.

Habel, Norman C. "The symbolism of wisdom in Proverbs 1-9." Interpretation 26 (1972): 131-57.

Halot. Koehler, Ludwig, Baumgartner, Walter and Stamm, Johann J. The Hebrew and Aramaic Lexicon of the Old Testament. Translated and edited under the supervision of M.E.J. Richardson. 4 vols. Leiden, 1994-1999. Electronic version used.

Hartenstein, Friedhelm. Das Angesicht JHWHs: Studien zu seinem höfischen und kultischen Bedeutungshintergrund in den Psalmen und in Exodus 32-34. Tübingen: Mohr Siebeck, 2008.

Hossfeld, Frank-Lothar and Zenger, Erich. Die Psalmen I: Psalm 1-50. Die Neue Echter Bibel. Würzburg: Echter Verlag, 1993.

Jäkel, Olaf. "Hypotheses revisited: The cognitive theory of metaphor applied to religious texts." Metaphorik.de 02 (2002): 20-42.

Kartje, John. Wisdom epistemology in the Psalter. Beihefte zur Zeitschrift für die alttestamentliche Wissenschaft 472. Berlin: De Gruyter, 2014.

Kraus, Hans-Joachim Psalmen, 1. Teilband. Biblischer Kommentar zum Alten Testament 15/1. Vierte Auflage. Neukirchen-Vluyn: Neukirchener, [1961] 1978.

Longman, Tremper III. Art. s.v. "Proverbs I: Book of." Pages 539-52 in Tremper Longman III and Enns, Peter (eds.), Dictionary of the Old Testament: Wisdom Poetry and Writings. A compendium of contemporary biblical scholarship. Downers Grove: Intervarsity, 2008.

Malina, Bruce J. Art. s.v. “Authoritarianism.” Pages 12-19 in Pilch, John J. and Malina, Bruce J. (eds.), Handbook of Biblical Social Values. Peabody: Hendrickson, 1998.

McKane, William. Proverbs: A new approach. The Old Testament Library. London: SCM Press, 1970.

Millard, Matthias. Die Komposition des Psalters. Ein formgeschichtlicher Ansatz. Forschungen zum Alten Testament 9. Tübingen: J.C.B. Mohr, 1994. 
Murphy, Roland E. "A consideration of the classification 'Wisdom Psalms." Pages 156-167 in Baumgartner, Walter (ed.), Congress volume. Congress of the International Organization for the Study of the Old Testament, Bonn 1962. Supplements to Vetus Testamentum, 9. Leiden: Brill 1963.

Pilch, John J. Article s.v. "Healing." Pages 102-6 in Pilch, John J. and Malina, Bruce J. (eds.), Handbook of Biblical Social Values. Peabody: Hendrickson, 1998.

Potgieter, J. Henk. "The structure and homogeneity of Psalm 32." HTS Teologiese Studies/Theological Studies 70(1) (2014): 1-6. Art. \#2725, 6 pages. https://doi.org/10.4102/hts.v70i1.2725.

Seybold, Klaus. Die Psalmen. Handbuch zum Alten Testament I/15. Tübingen: J.C.B. Mohr, 1996.

Terrien, Samuel. The Psalms: Strophic structure and theological commentary. Eerdmans Critical Commentary. Grand Rapids: Eerdmans, 2002.

Van der Lugt, Pieter. Cantos and Strophes in Biblical Hebrew Poetry with special reference to the First Book of the Psalter. Oudtestamentische Studiën 53. Leiden, Boston: Brill, 2006.

Weiser, Artur. Die Psalmen. Erster Teil: Psalm 1-60. 4. Auflage. Das Alte Testament Deutsch. Göttingen: Vandenhoeck \& Ruprecht, 1955.

Weber, Beat. Werkbuch Psalmen I, Die Psalmen 1 bis 72. Stuttgart: Kohlhammer, 2001.

Prof Phil J. Botha, Department of Ancient Languages and Modern Languages and Cultures, University of Pretoria, South Africa. Email: phil.botha@up.ac.za ORCID: https://orcid.org/0000-0003-1910-8372 